\title{
Appendix: Two Faces of Public Debt
}

\subsection{The Two Faces of Public Debt ${ }^{1}$}

\begin{abstract}
Public debt is at the same time private wealth. Both sides of the phenomenon have to be kept in mind when considering the optimal budget. When there are low real interest rates and high trade surpluses, reducing public debt is the wrong policy.

(Blurb by the FAZ editors-author's note.)
\end{abstract}

Firstly, Germany has a highly developed welfare state. Secondly, the free exchange of goods, all across Europe and indeed all around the world, is a key element of the German economic system. Thirdly, to the acclaim of voters, German policy is committed to the goal of price stability. Is the debt brake compatible with these three guiding principles of German economic policy? I doubt it. In the German discussion, public debt is only seen in a negative light—wrongly, as I will show.

Explicit and implicit public debt in Germany comes to around 10 trillion euros. This corresponds to private assets of citizens of exactly the same amount. The citizens are the state's creditors: partly, in the form of explicit claims on the state equivalent to the explicit public debt; and, to a greater extent, in the form of implicit assets in the form of retirement benefit and pension claims for which they have paid in the past by way of contributions and deductions from their salaries (in the case of

\footnotetext{
${ }^{1}$ Originally published in the Frankfurter Allgemeine Zeitung (FAZ) of June 4, 2010, p. 12. 
civil servants). Implicit claims on the healthcare system and to assistance in the case of need (welfare and unemployment benefits) are also implicit wealth for citizens and implicit public debt of exactly the same amount for the state. The wealth of citizens corresponding to the public debt of around 10 trillion euros is equivalent to approximately five times annual private and public consumption.

The total private net wealth of citizens is, of course, even greater. In addition to the net claims on the state just mentioned, there are also real assets in the form of real capital invested in Germany. This consists of real estate, plant and equipment, and inventories. Furthermore, Germans have net foreign claims. The sum of the assets consisting of real capital invested in Germany and net foreign claims is approximately equal to the net claims on the state. The total private net wealth of Germany's residents thus comes to around 20 trillion euros or around ten times annual private and public consumption. It is thus the equivalent of ten years of consumption in Germany. I refer to the ratio of private wealth to annual private and public consumption as the "saving period." The German saving period is thus around 10 years. It is equivalent to per capita wealth of around 250,000 euros.

This saving period of ten years can be attributed to German demographics and to the welfare state that Germany has built up over the last 120 years. Life expectancy has risen substantially during this time. It comes today to around 80 years and is continuing to rise. The increase in life expectancy has been connected to a steady increase in the average retirement period. Over the course of the last 40 years, the average amount of time during which retirees receive benefits from the social security system has increased from 10 to 17 years, thanks to more effective health care, decreasing health risks from environmental pollution, citizens' changed lifestyles and consumption habits, and changed and hence "healthier" working conditions.

We are considering explicit and implicit wealth in the form of the claims amassed by an active worker or a retiree enrolled in the social security system. There is a rule of thumb, which I cannot elaborate upon here: This wealth is, on the average for all age cohorts, equivalent to a saving period that is exactly half of the average retirement period, i.e., a saving period of eight-and-a-half years. This saving period includes the retirement benefit claims deriving from paid contributions (including those of employers). It also includes wealth in the form of claims on the healthcare system: Health insurance premiums in the public health insurance system bring about substantial implicit "savings" for old age, since they are not, after all, a function of age for people who are still economically active, even though healthcare costs are highly dependent on age. Public nursing care insurance premiums are also, to a large extent, claims amassed by beneficiaries. Finally, the welfare system is also, in part, a sort of implicit saving for the risk of poverty in old age. In addition, there are also the private savings of this population group.

In other words, if both our social security system and our welfare system worked like the funded schemes that are customary in private insurance, then they would have a capital fund to cover their future obligations to beneficiaries and, together with beneficiaries' private savings, this fund would amount to around eight-and-a-half times the beneficiaries' annual consumption. 
We can use the same rule of thumb to calculate the wealth amassed for retirement purposes among the parts of the population that are not covered by the social security system. These consist of entrepreneurs, freelancers, senior management and civil servants. The latter, in particular, have considerable pension claims. In addition to saving for one's old age (and that of one's spouse or partner), wealth is also left as an inheritance. Inheritance plays a major role in Germany. To a very large extent, business assets, for example, are left to children as an inheritance or transferred to foundations. Civil servants and senior management often leave unencumbered residential property to their children and also financial assets. Hence, on my estimate, the wealth of this stratum of the population is equivalent to around twelve times the annual private and public consumption attributable to it. The saving period is thus around 12 years here.

This brings us to an overall average for explicit and implicit private wealth for retirement and inheritance purposes equivalent to a saving period of ten years. What is important about this explanation of private wealth is that this ten-year saving period is a kind of structural parameter, which cannot be changed without massively altering the welfare state or the country's social structure. In order substantially to reduce this ten-year saving period, it would be necessary either to undertake deep cuts in public retirement benefits or to make private retirement planning and inheritance impossible for better-off strata, whether through taxation or by other means. Both steps would ultimately be tantamount to destabilizing our market-based democratic social order.

Could the private capital supply be placed domestically, if the state did not have any demand for capital? Today, such private real assets come to approximately four times annual consumption. This is the result of investment activity in a period of predominantly low real interest rates that has persisted for a long time. Investment always involves risk. Firms only invest if they expect a return that is considerably greater than zero. Under conditions of price stability, there is little scope for further interest rate cuts that could possibly result from a reduction in public debt. For nominal interest rates cannot fall below zero. Hence, I do not see any significant potential to absorb the existing high capital supply in the production of goods.

In other words, the theory according to which private investment is crowded out by public debt is no longer valid for Germany today. It would be valid if we had high real interest rates, which served to make it more difficult for the private sector to have access to the capital supply, in order thus to facilitate the sale of public debt instruments. With a large enough clientele and enough equity, entrepreneurs do not have any difficulty in financing investments via loans in our banking system. In light of the provision for retirement and inheritance discussed above, an insufficient supply of savings is never the reason for the failure of domestic investment plans. Reducing public debt thus does not lead to more real capital in Germany.

The contrary is to be feared. An extremely thrifty fiscal policy will lead to cuts in public investment in infrastructure. Transport routes will be neglected; school buildings will remain in their current poor condition given the desolate state of municipal finances. The bottlenecks in the normal course of economic and social life for which the public authorities are responsible will become more and more 
painful-among other things, at the expense of future economic growth and future tax revenue.

A reduction of public debt leads to increased capital exports. The shortfall in domestic demand corresponding to the smaller budget deficits will stimulate exports and restrict imports. Thus, more foreign assets can be accumulated through domestic saving. But this recipe for increasing economic wealth has an Achilles' heel, which has been revealed by the Greek crisis. How secure are foreign assets? The only possible target countries for rational investment of private wealth are the rich countries or China. The demographics of all these countries are similar to those of Germany. Life expectancy is similarly high — even in China. The retirement period is similarly long. Desire to leave an inheritance to one's children is no less or only slightly less than in Germany. Ultimately, these countries thus also have a similar saving period as Germany and hence an excess of private wealth.

Although a developing country, China exports, on balance, more capital than it imports. This is because, given the absence of a social safety net, private savings are so high that even the frenetic domestic investment activity is not enough to absorb all the savings. The International Monetary Fund is hoping that the global economy will be stabilized thanks to the introduction of a public retirement plan in China, which would lead to a decline in saving and an increase in consumer demand. The IMF is thus hoping for a stroke of the pen from the Chinese government that will lead to a drastic rise in implicit public debt.

But can it be right for global prosperity that China massively increases its public debt, while Germany is reducing its public debt? Both countries are significant net exporters of capital. If China reduces its trade surpluses by introducing a social security system, should this be offset by increased German trade surpluses? What then of the trade deficits of the USA, Portugal, Ireland, Greece, Spain (the PIGS), Hungary, the Baltic States and many others, which are the necessary correlate of the trade surpluses of Germany, China and a few other countries. For there are no trade surpluses without trade deficits. Are not countries with trade deficits everywhere being encouraged to return to the path of virtue, to tighten their belts, to reduce their budget deficits and hence also their trade deficits? How is this compatible with a German policy that increases Germany's trade surpluses?

In light of the persistently low real interest rates and the structural excess of private capital supply over private real capital demand in the relevant countries, the goal cannot be a collective lowering of public debt. There is no crowding out of private investment by public deficits in the global economy consisting of the rich countries and China. There is only a problem of excessive public debt in individual countries with high current account deficits, such as Greece, for example, or the USA. As long as creditors' confidence in these deficit countries (mistakenly) remained intact, their high demand contributed to a global economic bubble, from which, among others, German exports also greatly benefited. The fact that Germany ran no deficit in its 2007 budget was thanks to this bubble. We owe this to Greece, the USA and the other countries with trade deficits. At the time, all the savings of German households went into capital exports, since both the state and the corporate sector were self-financing. In particular, the longstanding US trade deficit and the 
euphoria triggered by the euro in the Southern and Eastern European countries have covered up the excess of private capital supply as compared to private capital demand.

But today the capital markets no longer have confidence in the deficit countries. Most of these countries have to consolidate their finances radically. Even the United States is undergoing an awakening and adapting to the reality. Americans are beginning to save again and are thus in the process of joining the countries with a structural excess of private capital supply. The USA will no longer be the "engine" of the global economy or at least it will not regain the same force that it had previously. If the IMF has its way, American deficits will be replaced as "engine of the global economy" by the implicit Chinese budgetary deficit that the introduction of a public retirement plan will suddenly bring about. There appears to be no solution without public deficits.

Public debt has two faces. On the one hand, it potentially competes with private borrowers who are seeking loans to form real capital (potential crowding-out). On the other hand, it corresponds to private wealth of exactly the same amount, which gets added to the real assets of the global economy, thus allowing for a level of retirement savings that goes beyond the capital uptake capacity of the productive sector. Which of the two faces is the decisive one for economic policy can be read off from the real interest rate level. If the latter is high, then public and private demand for credit are in competition with each other: Less public debt lowers interest rates and creates more room for real capital formation. If, when prices are stable, the real interest rate level, and hence the nominal interest rate level, is low, then it cannot fall any further from reducing public debt, since nominal interest rates cannot become negative. Reducing public debt does not have any effect of stimulating investment in this situation. To the contrary, since aggregate demand also falls along with this reduction, investment will tend to decline.

We need to find a common approach to the right amount of public debt on a global scale. The duty of a country to consolidate its finances and to reduce its public debt is all the more paramount, the higher its current account deficit. Conversely, however, countries with current account surpluses can also have a duty to increase budget deficits. For a generalized reduction in public deficits may simply lead to a crisis, since, precisely because of the low interest rates, private investment will not replace the public demand that is lost.

Greece, Portugal and Spain can only succeed in consolidating their finances if the economy in Europe is good, and this might require countries like Germany to expand, rather than limit, their structural, i.e., non-cyclical, budget deficits. For climate policy, it may make sense for individual countries to lead by example in reducing $\mathrm{CO}_{2}$. But in the case of public debt, this kind of "eager beaver" approach can be precisely the wrong one. The best contribution Germany can make to overcome the European sovereign debt crisis may be a significant lowering of German taxes.

Things would be completely different if real interest rates were high, so that a joint consolidation of public finances would lead to lower interest rates and a corresponding increase in private investment. The lesson that has to be drawn from 
this is that the right public debt policy is heavily dependent on the level of real interest rates. A rigid debt brake, such as the one now planned for Germany, cannot be the right way. With the required consolidation of finances in many other European countries, it can even lead to a depression.

As history teaches us, a depression will destroy free international trade and reinforce the disintegrative tendencies in the European Community - to the great detriment of the German export industry. It would be a fatal error, if a false, because purely negative, understanding of public debt would destroy the integrated global economy and hence, ultimately, strike the free market economy at its very core.

But how can the confidence of the capital markets be restored, if we want to avoid a race among countries to reduce their public debt that will result in a depression? At least to a large extent, the form taken by public debt should be a different one. There is a fear that high public debt could lead countries to abandon price stability. Inflation-indexed bonds are one possible response. These are gradually becoming more common. But we can also go one step further: I propose government bonds whose coupon is indexed to the growth rate of a country's (nominal) national product. In this case, the state's interest payments would always move in parallel to its tax revenue, which rises and falls with national product. Government bonds of this sort can also be an attractive form of investment for the country's citizens. Investors are, so to say, in the same boat as their co-citizens, with whom they tend to compare themselves. At a given public debt ratio, the country can improve its credit rating by issuing such bonds instead of conventional ones. This enlarges the scope for raising the level of public debt, thus allowing the population's desire for amassing retirement savings to be better accommodated.

Public debt is at the same time private wealth. Both sides of the phenomenon have to be kept in mind when considering the optimal budget. When there are low real interest rates and high trade surpluses, reducing public debt is the wrong policy.

Open Access This chapter is licensed under the terms of the Creative Commons Attribution 4.0 International License (http://creativecommons.org/licenses/by/4.0/), which permits use, sharing, adaptation, distribution and reproduction in any medium or format, as long as you give appropriate credit to the original author(s) and the source, provide a link to the Creative Commons license and indicate if changes were made.

The images or other third party material in this chapter are included in the chapter's Creative Commons license, unless indicated otherwise in a credit line to the material. If material is not included in the chapter's Creative Commons license and your intended use is not permitted by statutory regulation or exceeds the permitted use, you will need to obtain permission directly from the copyright holder.

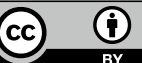

